\title{
Kulla-Gulla och alla de andra: Martha Sandwall-Bergström 100 år
}

\section{Av Helene Ehriander}

Smålandsförfattaren Martha Sandwall-Bergströms böcker om Kulla-Gulla läses än, men böckerna om Majken, Pepita och Arabella går inte längre att få tag på. Hon var på flera sätt en pionjär då hon i Kulla-Gulla-böckerna skildrade Fattigsverige och böckerna om Majken Stolt tillhör den första arbetarlitteraturen som skrevs med ungdomar som målgrupp, men ofta kallades hon "flickboksförfattare" med en nedsättande ton. I samband med 100-årsfirandet har ett Martha Sandwall-Bergström sällskap bildats och i november hölls på Linnéuniversitetet en konferens med titeln "Kulla-Gulla och alla de andra. Martha Sandwall-Bergström 100 år”.

En aprildag 1993 träffade jag Martha SandwallBergström i hennes lägenhet i Malmö. Hon berättade då öppenhjärtligt om sitt författarskap och hur det känts att samtidigt älskas av läsarna och föraktas av kritiken. Denna artikel bygger på det som hon berättade vid vårt möte; ett möte som gjorde djupt intryck på mig och som gav mig djupare förståelse för såväl hennes verk som författandets villkor under den tid hon var aktiv som barn- och ungdomsboksförfattare. Efter andra världskriget växte det fram en svensk barn- och ungdomslitteratur av hög kvalitet som vann erkännande också internationellt. Martha Sandwall-Bergström tillhörde de författare som debuterade 1945 och hennes böcker om Kulla-Gulla fick internationella framgångar och översattes till flera språk.

Martha Sandwall-Bergström föddes 1913 i Små-

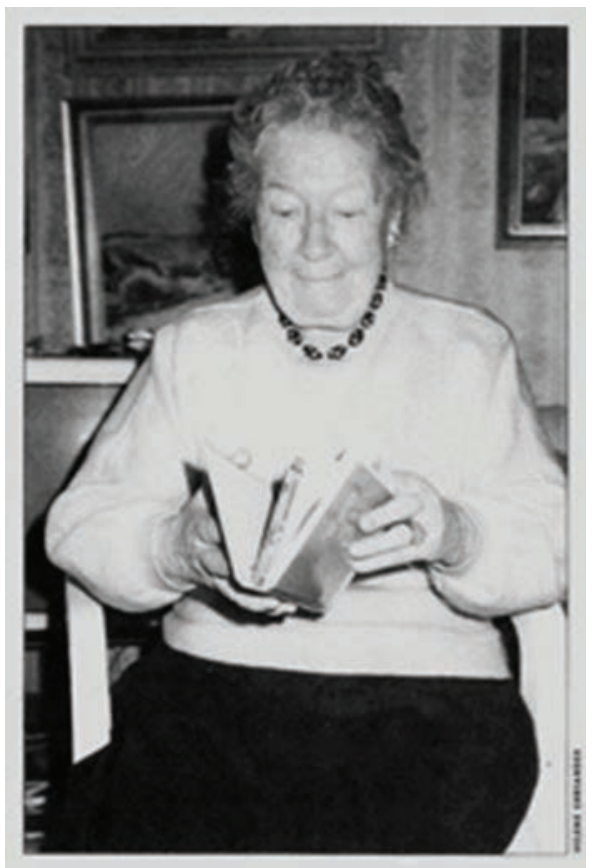

Martha Sandwall-Bergström 1993.

Foto: Helene Ehriander land, på gränsen mellan Nävelsjö och Lannaskede socknar en bit väster om Vetlanda. Det var en mycket glest bebyggd och isolerad trakt. Det var här hon mötte de gestalter som sedan omstöptes och tog form i böckerna om Kulla-Gulla. Det var tysta, tunga personer, som led av fattigdom och hjälplöshet, men som ändå aldrig klagade.

”Jag har träffat alla dessa gestalter och fascinerats av deras öden”, berättade Martha Sandwall-Bergström. "Kulla-Gulla finns förstås inte på riktigt, men hennes förebild he- 
ter Ingrid Alm och bor idag i Stockholm. Hon var min väninna och bodde på ett av dessa torp, som jag skildrar i böckerna.

Någon herrgårdsfröken blev hon aldrig, men jag önskade henne allt gott och därför lät jag henne spela den rollen. Egentligen var kanske min väninna mer lik Johannes till sättet. Herrgården som hon använde som modell hette Svartåsen och låg på en ås ovanför Lannaskede hälsobrunn, där Martha Sandwall-Bergström då bodde. Fast en del av miljön hämtade jag från Surahammars bruk i Västmanland.”

Socialt engagemang och medvetenhet finns i alla hennes böcker, parallellt med romantiken och drömmarna. Den första boken om Kulla-Gulla kom 1945. Den skrev Martha Sandwall-Bergström under en kort tidsperiod och manuskriptet skickade hon till en tävling om bästa flickboken som Bonniers anordnat.

"När jag fick reda på att jag vunnit, hade jag nästan glömt bort tävlingen", sade hon. ”Jag hade heller ingen tanke på att skriva någon fortsättning, men Gerhard Bonnier ringde och övertalade mig.”

\section{Försörjde familjen}

Det var emellertid inte Martha Sandwall-Bergströms första berättelse. Under många år hade hon då redan försörjt sin familj med sin penna genom att skriva noveller för flera olika tidningar.

”Jag skrev mycket redan som barn och jag har alltid velat skriva. Min syster skrev också, men hon gömde sitt. Jag lade fram mina alster halvfärdiga så att alla kunde se dem, och ofta var den sista meningen halvfärdig för att jag ville att någon annan i familjen skulle fortsätta berättelsen.”

När Martha sedan blev vuxen och fick egen familj blev hon tvungen att ensam lösa försörjningen av den. Hennes man blev svårt sjuk och handikappad och deras lilla dotter visade sig ha en grav hjärnskada. Någon hjälp fanns inte att få på fyrtiotalet och Martha skrev, medan hon passade flickan och hjälpte mannen.

Ofta skrev hon under pseudonym, eftersom hon var nödsakad för inkomstens skull att skriva för flera olika veckotidningar samtidigt, men ibland var det inget problem då tidningarna inte alltid satte ut något författarnamn.

”Kulla-Gulla har blivit mest känd för att böckerna låg så rätt i tiden när de kom”, sade Martha Sandwall-Bergström. ”Det ligger för mig, det som är lite rörande, och jag vill gärna att de som har det lite svårt ska få det bra, precis som gestalterna i mina böcker. Jag tycker om när människor rörs över livet och jag vill bara nytta och välsignelse med böckerna."

\section{Kritiserad fortsättning}

"Jag tänkte att om jag skriver om en god och rar flicka så skulle läsarna ta efter och fundera över sin egen karaktär och sitt eget sätt att vara. Jag skrev till en början helt aningslöst, så äkta och ärligt jag kunde, utan tanke på kritiker och deras sätt att se på 
böcker. "De två första böckerna blev uppskattade, men sedan fick kritikerna ögonen på fortsättningarna."

Och kritiken var många gånger hård mot Martha Sandwall-Bergström och Kulla-Gulla. Eva von Zweigbergk i DN skrev vid flera tillfällen så skarpt om Kulla-Gulla-böckerna att Martha kände sig hämmad och förkrossad.

”Jag försökte forma mig och anpassa mina gestalter, så att de inte skulle besvära kritikerna i fortsättningen. När jag skulle skriva satt jag med skrivmaskinen framför mig och kände det som fingrarna knöt sig i kramp. Jag tänkte på vad som skulle stå i tidningarna sedan om mina böcker, att de liknades vid veckotidningsnoveller och att det var skamligt att skriva flickböcker!"

"Idag känner jag det inte så längre och jag har inget emot att kallas flickboksförfattare. Det har ingen dålig klang längre och jag vet att mina böcker kommit ut i många upplagor och blivit älskade av många flickor. Vad gör det då att kritikerna trampade mig under hälarna? Det är konstigt också att det ska vara suspekt att vara framgångsrik bland läsarna”, menade Martha Sandwall-Bergström.

Martha Sandwall-Bergström berättade också att KullaGulla nog är den gestalt, som hon själv tycker mest om, eftersom hon är som ”ett öppet pulserande hjärta” och eftersom det varit så mycket bråk om henne att hon genom de mödorna kommit att fästa sig vid henne.

Genom åren fick Martha Sandwall-Bergström många brev från flickor som undrar hur det gick sedan för Kulla-Gulla, om hon blev lycklig med Tomas och om de fick några barn.

"Jag vet inte hur det fick för dem egentligen och jag

Den första boken om Kulla-Gulla vann pris i Bonniers tävling om bästa flickbok 1945. Den var Martha Sandwall-Bergströms debutbok. 1986 blev den TV-film med Lisa Jarenskog i huvudrollen. vill inte skriva om det heller. Istället fick jag med tiden idén att gå tillbaka i tiden och skriva om hur Kulla-Gulla hade det innan hon kom till Kulla-torpet."

Det var så bilderböckerna kom till.

"En del, som ligger mellan Kulla-Gulla på Blomgården och Kulla-Gulla, har jag försökt skriva många gånger, men den vill sig inte och den kommer säkert aldrig att bli färdig. Jag hade tänkte att den skulle heta Gulla yngsta ostapiga!”

"Eftersom jag var bunden till hemmet och vårdandet fick jag skriva om det jag såg nära omkring mig”, förklarade Martha Sandwall-Bergström. ”Böckerna om Majken kom till genom att jag kände en familj som var lik familjen Oskarsson. De bodde i arbetarbostäder på Lidingö, när vi bodde där.”

"Majken är en käck flicka och miljön har nog blivit rätt lyckad eftersom jag kände den så väl. Men ingen miljö kan jag känna så för som den småländska barndomsmiljön”, betonar Martha.

"Samhällsengagemanget och medvetenheten som står så tydlig för läsarna var inte direkt eftersträvad”. Martha menade att den snarare kom sig av hennes människosyn och 
känsla för medmänniskorna. De tre böckerna om Majken Oskarsson är helgjutna och tål mer än väl en omläsning. De har tyvärr försvunnit ut på bibliotekens magasin idag, men de som ger sig tid att leta upp dem blir belönade med en intressant skildring av en viljestark flicka i en för ungdomsromaner annorlunda miljö.

\section{Pepita och Arabella}

Böckerna om Pepita och Arabella utspelas i Spanien. Sedan 1950 har Martha SandwallBergström i långa perioder bott i Spanien och inspirationen till dessa böcker kom genom att hon fantiserade kring en del små spanska flickor, bland annat några tiggarflickor, som hon mötte där. Martha reagerade också starkt på flickors och kvinnors roll i Spanien. De flickor som skildras i böckerna är starka, kloka och ärliga, med ett mål i livet.

"Men det är inte bara en eftergift åt flickbokskonventionen", påpekar Martha bestämt. "Jag ville skildra positiva flickor. Dessutom måste ju alltid huvudpersonen föra handlingen framåt i boken, antingen det är en flicka eller pojke”.

\section{rose}

Denna artikel är en omarbetad version av en artikel som var publicerad i den numera nedlagda barnkulturtidskriften Abracadabra (Ehriander, Helene, "Älskad av läsarna men föraktad av kritiken”, Abracadabra, 1993:3, s. 3-5).

पode

\section{Välkommen att gå med i Martha Sandwall-Bergströmsällskapet!}

Som medlem får du:

- sällskapets medlemsbrev med information om författaren, hennes liv och verk

- ta del av icke tidigare publicerade texter av Martha Sandwall-Bergström

- information om föreläsningar, seminarier och konferenser som handlar om Martha Sandwall-Bergströms författarskap eller angränsande ämnen.

Medlemsavgiften (150:-) betalar du in på bankgiro 147-8973.

OBS! Vid inbetalning lämna både postadress och - om du har - mailadress!

Besök även vår hemsida: http://sandwallbergstromsallskapet.blogspot.se 